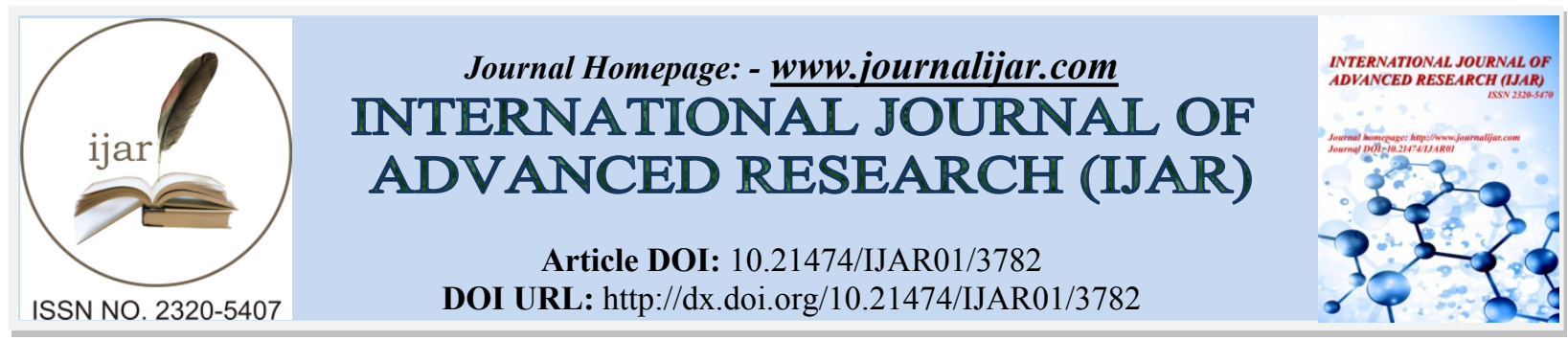

RESEARCH ARTICLE

\title{
FACTORS INFLUENCING GOVERNMENT PROCUREMENT OPPORTUNITIES FOR DISADVANTAGED GROUPS IN PUBLIC INSTITUTIONS AT KENYA PORTS AUTHORITY.
}

\author{
Stephen Chepsoiyo Chepkangor ${ }^{1}$ and Gabriel Lubale ${ }^{2}$. \\ 1. MSC Student, Jomo Kenyatta University of Agriculture and Technology. \\ 2. Lecturer, Jomo Kenyatta University of Agriculture and Technology.
}

\section{Manuscript Info}

Manuscript History

Received: 09 February 2017

Final Accepted: 01 March 2017

Published: April 2017

Key words:-

Government, Procurement,

Opportunities, Disadvantaged Groups

\begin{abstract}
The purpose of this study is to develop insight into the Factors influencing Government Procurement Opportunities for Disadvantaged Groups in Public Institutions using Kenya Ports Authority as a case study. Other studies have argued that there have been less success in the implementation of the programme in Kenya due to various reasons. However, some of the factors that are used to determine the levels of success might vary from one institution to another considering that they might not be working on the same level.

The premise of this study is to identify specific factors that influence success in implementation of such special programmes as envisage by the Government of Kenya from time to time. This study finds evidence that suggests that Youth, Women and Person with Disabilities who are disadvantaged in several ways. It is on the context that the research finds that there is a probability of less success in implementation of such programme now or in the new future if some of the key challenges are not address now. The target population under study was 400 individual including in the 3 different categories covering Youth, Women and People with Disabilities, all should be individuals who have experience or knowledge in the procurement services in the Government sector. A conclusion on factors influencing Government Procurement Opportunities for Disadvantaged Groups in Public Institutions in Kenya was observed by the researcher.
\end{abstract}

Copy Right, IJAR, 2017,. All rights reserved.

\section{Introduction:-}

Given that government procurement constitutes a significant proportion of gross domestic product, it is of considerable importance at both domestic and international level. Estimates have indicated that overall government procurement spending accounts for as much as 20 to 30 percent of a country's gross domestic product, on an average, worldwide. At the domestic level, the procurement of goods, services and technologies by government agencies provides essential inputs that enable governments to deliver public services and fulfill other tasks and catalyze economic growth. At the international level, the opening up of cross-border trade in this market is gaining increasing importance.

Especially in the developing countries, they have a far deeper impact, as the government is involved in these countries in everyday lives of its citizen especially in the development of infrastructure and promotion of industrial 
sector which are important catalysts for development. (Kumar, 2012). According to Muraguri, 2013, Public procurement has been a neglected area of academic education and research, even though public procurement is alleged as a major function of government and even though governmental entities, policy makers and public procurement professionals have paid a great deal of attention to procurement improvements or reforms. Investing in women-owned businesses pays dividends in terms of creating jobs and development. Small and medium-sized enterprises are the engines for job growth in the world economy, accounting for nearly $80 \%$ of jobs worldwide. Increasing their competitiveness increases their likelihood of success, expansion and job creation. Women entrepreneurs tend to reinvest up to $90 \%$ of their earnings in their families and Communities, which links inclusive economic growth directly to development (González, 2014)

\section{Development of preference and reservation policy in Kenya:-}

The new public procurement Act under chapter XII acknowledges importance of preference and reservation even prescribes percentages for specific target groups such as women youth and people with disability. (ROK, 2015).

\section{Kenya Ports Authority:-}

At the port, various types of goods are handled which include containers, general cargo, liquid and dry cargo and passengers. It provides deep water anchorages and mooring buoys for sea going ships. The port has two oil terminals; the Kipevu oil terminal situated on the mainland Portreitz area and Shimanzi oil terminal. They are well equipped with crude oil and tankers and slop tanks to handle large amount of oil. Vegetable oil handling and storage facilities are available and are operated by two private companies Gulf Stream and East African Storage. The running of the port was then taken over by the national government. On $20^{\text {th }}$ January 1978 under an Act of Parliament (Cap 391), a statutory body under the Ministry of transport was established with the mandate to maintain, operate, improve and regulate all scheduled seaports along the Kenyan coastline. The organization therefore falls under public entries which by the current procurement law must ascribe to its rules of which one requires that $30 \%$ of its procurements must be reserved for the disadvantaged groups.

\section{Public procurement frameworks:-}

Public procurement frameworks in developed and developing countries alike face the public expectations of transparency and accountability and of efficiency and effectiveness of resource management. In addition, the procurement environment is characterized by conflicting stakeholder interests at the political, business, community and management levels and further exacerbated by competing claims between executives, lawyers, technologists and politicians for lead roles in this arena Muraguri, 2013. In a developed or developing country, public procurement practitioners have and will always face many challenges. Each country has its own economic, social, cultural and political environment, and each country's public procurement practitioners face different types of challenges, or the same types of challenges but at different levels from their counterparts in other countries. Corruption is disastrous to the sound functioning of any government department. It diverts decision-making and the provision of services from those, who need them to those, who can afford them (Marguri, 2013). Achura, et al.., 2005 examined the effectiveness of public procurement audits for constituency development funds in Kenya. However, they did not address the challenges facing the implementation of procurement regulations in Kenya. Ngugi et al. 200, examined impact of procurement activities on the operation and effectiveness of public sectors in Kenya and concluded that it is essential that these activities be performed by qualified staff with high professional and ethical standards and using sound procedures anchored in appropriate policies and regulations.

\section{Public Interest Theories of Regulation:-}

In western economies, the allocation of scarce resources is to a significant extent coordinated by the market mechanism. In theory, it can even be demonstrated that, under certain circumstances, the allocation of resources by means of the market mechanism is 12 optimal (Arrow, 1985). Because these conditions are frequently not adhered to in practice, the allocation of resources is not optimal and a demand for methods for improving the allocation arises (Bator, 1958). According to public interest theory, government regulation is the instrument for overcoming the disadvantages of imperfect competition, unbalanced market operation, missing markets and undesirable market results(Arrow, 1970; Shubik, 1970).Vincent and Abbie(2011) proposed that sustainable procurement practices necessitates the appropriate order in pursuit of procurement activities to match with policies and best practices as to first conform with and surpass all relevant legislation and regulatory requirements including environmental, social, health and safety policies. 


\section{Institutional Theory:-}

The basic concepts and premises of the institutional theory approach provide useful guidelines for analyzing organization-environment relationships with an emphasis on the social rules, expectations, norms, and values as the sources of pressure on organizations. This theory is built on the concept of legitimacy rather than efficiency or effectiveness as the primary organizational goal (Doug and Scott, 2004). The environment is conceptualized as the organizational field, represented by institutions that may include regulatory structures, governmental agencies, courts, professionals, professional norms, interest groups, public opinion, laws, rules, and social values. Institutional theory assumes that an organization conforms to its environment. There are, however, some fundamental aspects of organizational environments and activities not fully addressed by institutional theory that make the approach problematic for fully understanding credit reference bureaus and their environment: the organization being dependent on external resources and the organization's ability to adapt to or even change its environment (Doug and Scott, 2004).

\section{Youth Empowerment Theory:-}

Hart's (1992) Ladder of Young People's Participation, based on Arnstein's (1969) typology of citizen control, and is an informative framework for articulating youth participation types. Hart's typology, however, does not take into account recent findings in youth-adult partnership research. By placing youth-driven participation at the top of the ladder, the contribution that adult-involvement can lead to youth and community development is undervalued. Furthermore, the lack of adult involvement in youth-driven participation may hinder rather than encourage optimal adolescent development and empowerment. In her evaluation of youth-adult partnerships, Camino (2005) found that activity quality and positive development outcomes could be compromised when adults are not involved.

\section{Conceptual framework:-}

Robson (2002) defines the conceptual framework of a study as the system of concepts, assumptions, expectations, beliefs, and theories that supports and informs research as a key part of the research design. The variables of the study comprised one dependent variable successful implementation of the Government Procurement Opportunities by Disadvantaged Groups and four independent variables that is Sensitization, level of education, Liquidity and Equity ratio (shareholding)

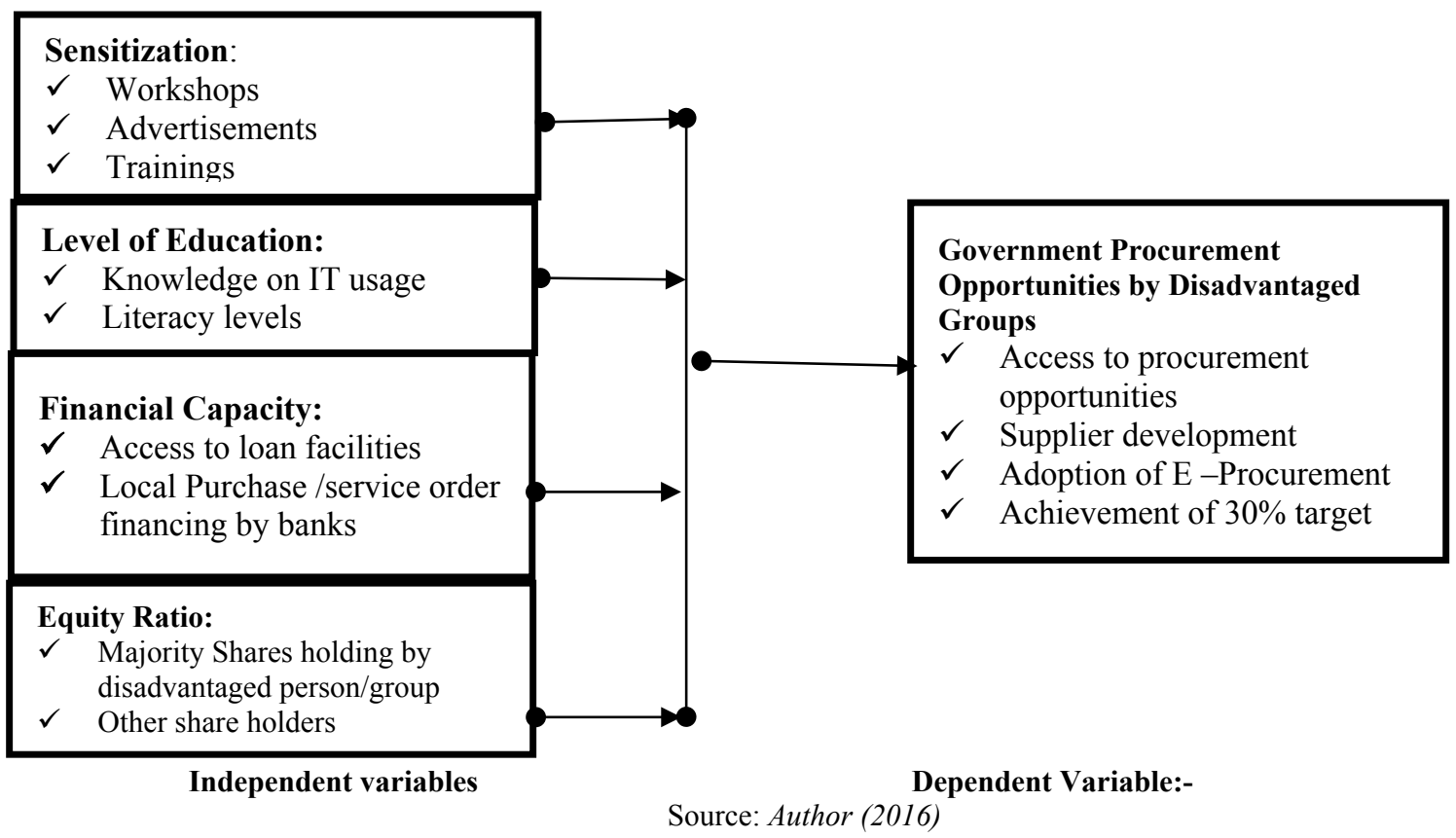

Introduction of new policies by any government or institution, however good it is will never realize its intended objectives if the target beneficiary groups and implementers, are not given the required knowledge on the same. Resources my go to waste and policy not seeing the light of the day if sensitization is not adequately planned and executed. Jonas and Tom (2014) argue that with Strong media attention and growing awareness among consumers 
about the need for sustainability initiatives, a company's reputation and brand image has become critically dependent on the inclusion of sustainability in sourcing decisions.

The Kenya National Youth Policy (2007) aims to enhance youth participation in national development goals and ensure that programs are well-coordinated to address the interests of youth (Government of Kenya, 2006). A complementary policy, the Youth Enterprise Development Fund, was formed in 2006 to increase access to capital for young entrepreneurs and to provide business development services, facilitate linkages in supply chains, create market opportunities locally and broad for products and services of youth enterprises, and facilitate infrastructure to support growth of youth businesses (Youth Enterprise Development Fund, 2009).

\section{Level of education:-}

Entrepreneurship, under Schumpeter, is thus the expression of the human impulse to be Creative (Khalil 2007) and the role of the entrepreneur in the growth economy is argued to be direct and unambiguous. Schumpeter's basic realization was that economic growth resulted not from capital accumulation, but from innovations and "new combinations" (Landström, 2005). Precisely, Schumpeter has declared that "the carrying out of new combinations we call 'enterprise'; the individual whose function is to carry them out we call 'entrepreneurs"'. The level of education plays a key role in the progressing the realization of the new policy on Preference and reservation groups. Since the target groups involves people of different categories in the society.

\section{Financial Capacity:-}

According to Public Procurement and Disposal (Amendment) Regulations, 2013. Kenya gazette Supplement No. 89 of 18th June, 2013 clause 33, a procuring entity shall facilitate financing of enterprises owned by youth, women or persons with disabilities that have been awarded contracts, by authenticating their notifications of tender awards and local purchase or service orders and subsequently entering into an agreement with the relevant financing institution with conditions that shall include paying the contracted enterprise through their account opened with the financier. Prompt payments for performed contracts. The speed at which the directive is adopted and implemented entirely depends to the various institutions. Having clear compliance framework and involvement of the public shall see this directive a success.

\section{Equity ratio:-}

According to John Stacey Adams, the principle of fairness and balance; where employee's degree of motivation is correlated to their perception of equity, fairness, justice... practiced by their management in the work place... When workers evaluate fairness they compare their job input to the organization and also their outcome. The UK government aims to increase rates of business ownership among disadvantaged groups and within deprived areas and acknowledges that poor access to finance is a barrier to enterprise in these communities (Julia at. El., 2006). The Kenyan government has acknowledged that women are 'disadvantaged' and has made a formal commitment to alleviate their situation. Economic and political crises, however, have tended to displace attention from the needs of oppressed groups in Kenya, including women (Rajah. F., 2007).

\section{Government Procurement Opportunities by Disadvantaged Groups}

"Disadvantaged group" means persons denied by mainstream society access to resources and tools that are useful for their survival in a way that disadvantages them or individuals who have been subjected to prejudice or cultural bias because of their identities as members of groups or categories of persons without regard to their individual qualities, and includes enterprises in which a majority of the members or shareholders are youth, women, persons with disability or categories as shall be prescribed;(Public Procurement and Asset Disposal Act 2015). Government procurement refers to procurements done by the government including state agencies

\section{Empirical Review:-}

According to research by (Maraguri, 2013) the following key issues affected the preference and reservation policy among the youth. (This policy is now covered well in the new Public Procurement and Asset disposal Act 2015). First inadequate training of procurement staff in organization had affected the implementation of 'preference and reservation regulations', second is incompetency of procurement staff in our organization has affected the implementation of 'preference and reservation regulations' and third is failure to employ good strategic sourcing practices in organizations has affected the implementation of 'preference and reservation regulations' as envisaged even as elaborated in the current PPDA of 2015 under Disadvantaged Groups 


\section{Critical Review of existing literature:-}

Under the research done by Muraguri (2013), it is evident that there are inadequate studies on the challenges facing the implementation of youth preferential procurement in public procurement in Kenya. Studies conducted in Kenya in the area have focused more on the effectiveness of procurement process in general. Ngugi \& Mugo (2007) analyzed the effect of procurement activities on the operation and effectiveness of public sectors in Kenya. Zomboko (2012) analyzed the challenges in procurement and use of donated medical equipment in referral hospital in Tanzania but failed to identify factor facing the implementation of preferential policy in procurement. In addition Harpe(2009) assessed public procurement law in South Africa but failed to establish the challenges facing the implementation of directive for allocation of public procurement to special interest groups. Maraguri (2003), only concentrated on the challenges faced by one part of the preference and reservation group that is youth and excluded Women and Persons with Disability who fall under the same disadvantaged group

\section{Research Gap:-}

Noting that the previous researcher's focus only on general procurement practices, therefore, these lacks conclusive studies in the area of public procurement for the preference and reservation target group as stipulated under the Kenyan constitution 2010 and Public Procurement and Asset Disposal Act 2015 and regulation 2006 and the recent presidential directive for all procurement entities to set aside $30 \%$ of their annual procurements to special interest groups (preference and reservation group) here referred to Disadvantaged Groups. Based on the above finding therefore, though the Act was recently enacted there is still lack of sufficient study in Kenya on the factors influencing government Procurement in public institutions by respective stakeholders. This forms the research gap, and this study seeks to examine factors influencing Government procurement opportunities by Disadvantaged groups at Kenya Ports Authority.

\section{Summary of literature Review:-}

The preference and reservation groups composed of youth women and people with disabilities is a great recognition by the government of Kenya to improve the lives of such group of marginalized persons. In some other countries like India such preferences appear under reservation of price on certain products to certain group of persons. Whereas in Europe such preferences groups appear in form of Small and Medium Enterprises.

\section{Research Design:-}

According to Mugenda \& Mugenda (2008), research design is the plan, structure and strategy of investigation conceived so as to obtain answers to research questions proposed in a research.

The research methodology used is a descriptive research and as such descriptive research design was adopted. The choice of this design was informed by the need to ascertain and be able to describe the characteristics of the variables of interest in the study without influencing it in any way. It involved observing and describing the behavior of a subject as it is.

\section{Population of study:-}

According to Kombo \& Tromp (2006). A population refers to an entire group of persons or elements that have at least one thing in common. According to Kenya Ports Authority supplier database 2016, there are 383 women, 377 Youth and 51 Persons with Disabilities are currently trading with its Procurement functions. The population target under research was the disadvantaged groups.

Table 3.1:- KPA Registered Disadvantaged groups as of 2016.

\begin{tabular}{|r|c|}
\hline Groups & Registered in KPA Database \\
\hline Women, & 383 \\
\hline Youth & 377 \\
\hline Persons with Disabilities & 51 \\
\hline Total & $\mathbf{8 1 1}$ \\
\hline
\end{tabular}

Source: (KPA, 2016)

\section{Sampling size:-}

Scholars do not agree on the exact proportion of the accessible population that should form the sample size. Mugenda and Mugenda (2008) suggest that in descriptive studies twenty percent (20\%) of the survey population is representative enough to generalize characteristics being observed. 
Table 3.2:- Sample Size.

\begin{tabular}{lccc}
\hline Target Group & $\begin{array}{c}\text { Target Population } \\
\text { (50\% of the Registered KPA suppliers) }\end{array}$ & Sample Size & (\%) \\
\hline Youth Groups & 192 & 38 & 20 \\
Women Groups & 189 & 37 & 20 \\
PWDs Groups & 26 & 5 & 19 \\
\hline Total & $\mathbf{4 0 6}$ & $\mathbf{8 0}$ & $\mathbf{2 0}$ \\
\hline
\end{tabular}

Source: Author

Target Population:-

The population under study was 811 person as shown in table 3.1 above, the study picked half of the Population understudy which give 406 persons to be the target population. The research thereafter sampled $20 \%$ of the target population of 406 person and thus the 80 persons used in the study as a sampled Population as shown in table 3.2 above.

\section{Sample Size and Sampling Technique:-}

According to Kothari (2010) sampling is the process by which a relatively small number of individuals, objects or events is selected in order to find out something about the entire population from which it was selected. Stratified random sampling was used in this study. Stratified random sampling technique was suitable as it gave each respondent in every disadvantaged category a chance of being selected and also ensures that all are represented. According to Kothari (2010) an optimum sample is the one that fulfills the requirements of efficiency, representativeness, reliability and flexibility. The sample ranged was between $10 \%$ and $30 \%$. The study targeted to use a sample size of $20 \%$ of the target population.

\section{Data Collection Instruments:-}

The main research instruments used in the study was a designed questionnaires. This enabled researchers to get needed information on the set objective mentioned in the study. In addition, document analysis was used in obtaining information from journals, reports and other resourceful material presented by other researchers which focus on this study.

\section{Data Collection Procedure:-}

Primary data was collected using questionnaires method. The questionnaires consisted of both open ended and closed ended questions covering issues related to AGPO implementation. Open ended questions gave the respondents allowance to freely respond to the questions without any limit and give their alternatives. According to Mugenda and Mugenda (2009), the open ended or unstructured questions permit greater depth of response from the respondents while the closed or structured questions are usually easier to analyze. Questionnaires were chosen because they were easier for the researcher to collect a lot of information over a short period of time.

\section{Pilot Study:-}

According to Mugenda and Mugenda, (2009), validity is the accuracy and meaningfulness of inferences, based on the research results. One of the main reasons for conducting the pilot study was to ascertain the validity of the questionnaire. In order to obtain reliability of the instrument, a test retest method was used.

\section{Data Processing \& Analysis:-}

Data processing and analysis was collected synthesized and presented using, tables for ease of understanding and narration .Kothari (2009) defines analysis as the computation of certain indices or measures along with searching for patterns of relations that exist among data groups. Descriptive statistics such as mean and standard deviation was used to present the various characteristics for data sets, supported by Cooper \& Schindler (2003).The data collected was sorted and coded then entered into the Statistical Packages for Social Sciences version 16.02 and descriptive statistics was be used to show the relationship between factors influencing government procurement and the defined Disadvantaged groups as stated in Public Procurement and Assets Disposal Act 2015. The regression analysis was used to establish the degree to which the four independent variables i.e. Sensitization, Level of Education, Financial Capacity and Equity Ratio, 
$Y=\beta 0+\beta 1 X_{1}+\beta 2 X_{2}+\beta 3 X_{3}+\beta_{4} X_{4}+\beta_{5} X_{5}+\varepsilon$

Where:

$\mathrm{Y}=$ Procurement for disadvantaged Group (achievement of 30\% target)

$\beta 0=$ constant or $y$-intercept

$\beta 1-\beta 5=$ regression coefficients

$\mathrm{X}_{1} \quad=$ Sensitization

$\mathrm{X}_{2} \quad=$ level of education

$\mathrm{X}_{3} \quad=$ Financial Capacity

$\mathrm{X}_{4} \quad=$ Equity Ratio

$\varepsilon=$ Error term

$\beta 1=$ measures the rate of change government procurement for disadvantaged groups as a result of a unit change in Sensitization.

$\beta 2=$ measures the rate of change in government procurement for disadvantaged groups as a result of a unit change in level of education

$\beta 3=$ measures the rate of change in government procurement for disadvantaged groups as a result of a unit change in Financial Capacity

$\beta 4=$ measures the rate of change in government procurement for disadvantaged groups as a result of a unit change in Equity ratios

\section{Data Presentation, Analysis and Interpretation:-}

The total target number was $80(100 \%)$ and the responses rate were $74(93 \%)$. This give a positive responses rate which is distributed among different categories. Results from the questionnaire are enumerated as indicated below:

\section{Demographic characteristics:-}

Gender:-Majority of the respondents were male, comprising $65 \%$, while women were only $35 \%$. This shows that male still dominant this business area just like in other general business areas.

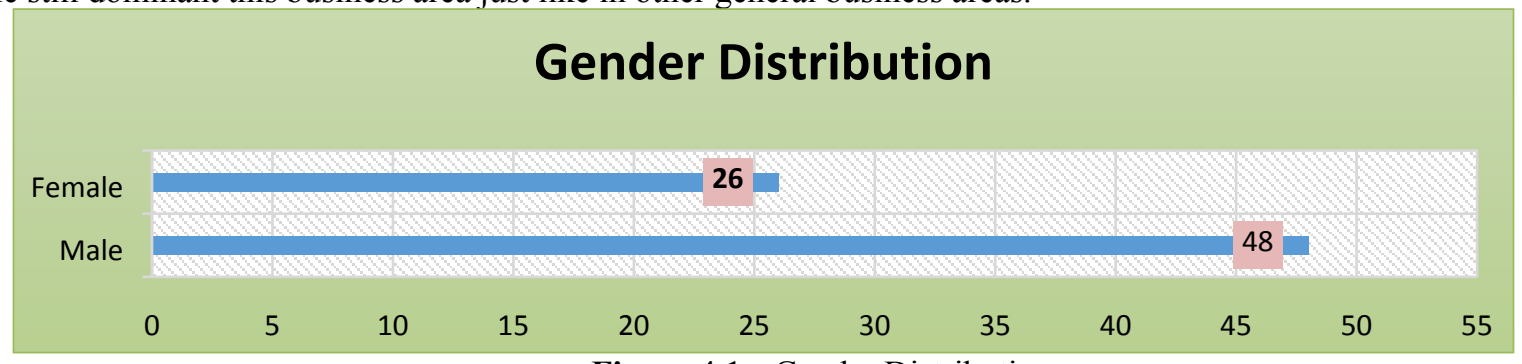

Figure 4.1:- Gender Distribution.

\section{Age Distribution:-}

A large number of the respondents (40.54\%) were aged between 31 and 45 years. Only a small regressive proportion of the respondents were aged below 31 years $(31.08 \%)$ and above 45 years representing $(28.38 \%)$. The trends shows that majority upon reaching age 46-54 leaves this category and mostly women, few youth and people with disability remains. It also demonstrated that an active business aged is between 31 up to 45 years old. (See figure 4.2 below).

\section{Age Distribution}

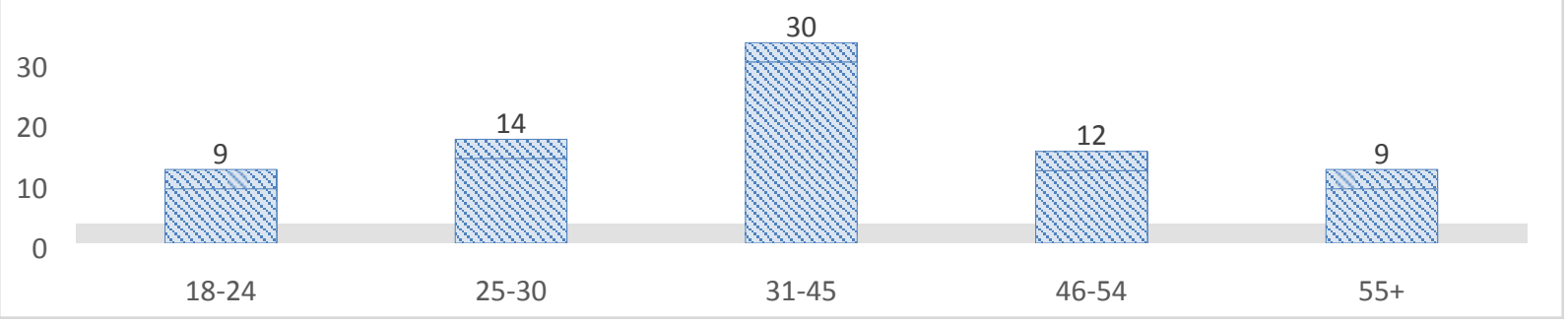

Figure 4.2:- Age distribution. 


\section{Marital Status:-}

A greater majority of the respondents were married $(73 \%)$ with only a small percentage $(27 \%)$ reporting single status.

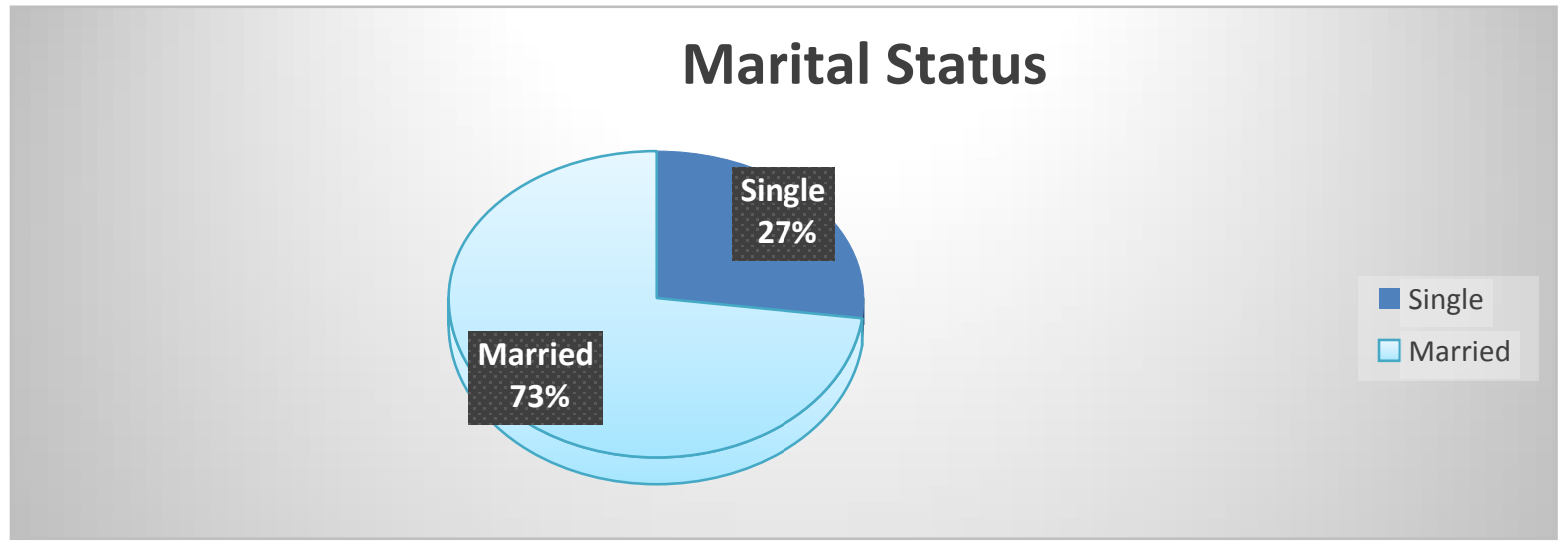

Figure 4.3:- Marital status.

\section{Respondents Category:-}

Women and Youth Category of the respondents showed that they are the majority in the cluster of disadvantaged groups with a closer in numbers (49\% and 46\% respectively) whereas Person With Disability are the list at (5\%) as indicated below

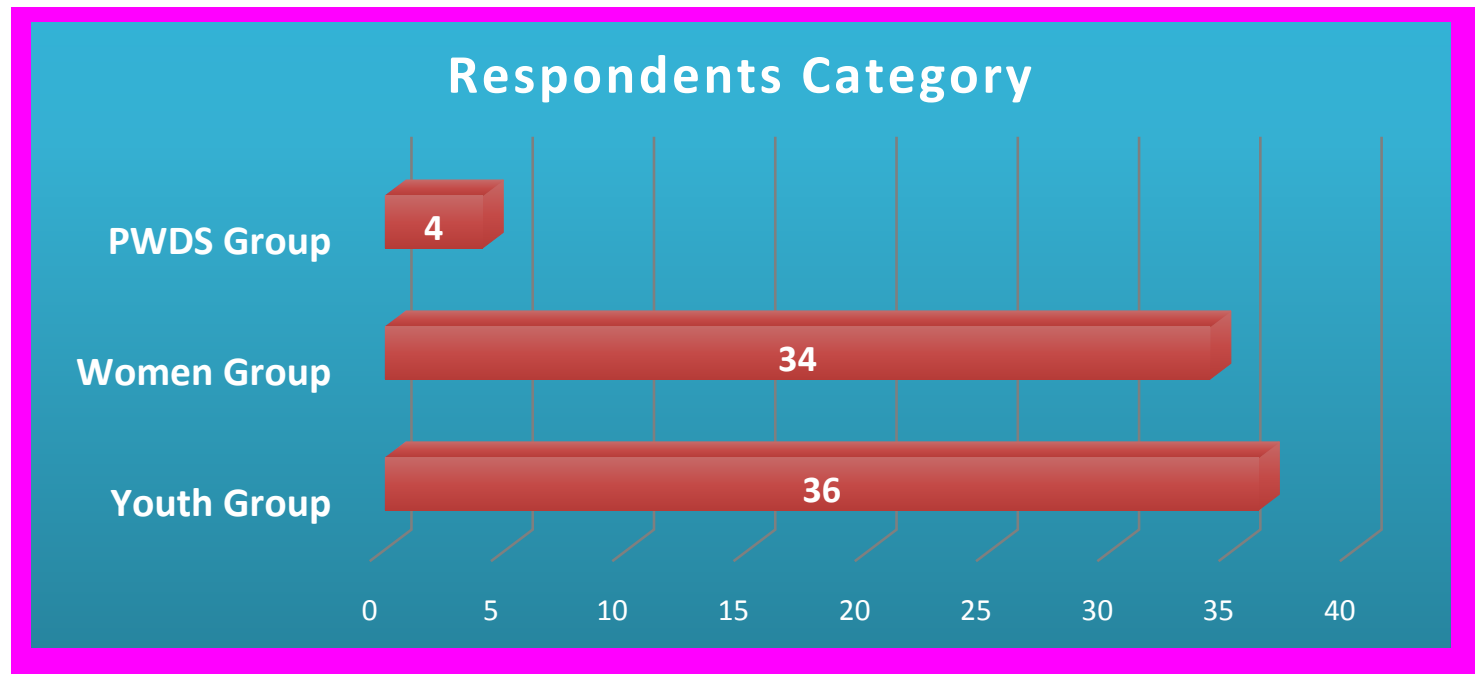

Figure 4.4:- Respondents Category.

Sensitization on existence of the law on preference and reservation groups:-

Aware on the law on preference and reservation for disadvantaged groups on Government Procurement:-

There was $100 \%$ confirmation that there is a law which takes care of the disadvantaged groups under preference and reservation category. There was also an affirmative agreement that a procurement entity is required to reserve $30 \%$ of its Annual Procurements to the Disadvantaged Groups. According to Kothari (2003) correlation analysis studies the joint variations of two or more variables Correlation of +1 means a strong relationship between the independent variables and the dependent variable. This study used Pearsons' correlation Model to test direction of correlation between the dependent variable and the various independent variables. This was supported by the finding of $100 \%$ confirmation from respondents. 
An Opinion about Kenya Ports Authority on the level of sensitization to current suppliers and prospective suppliers on changes and benefits accrued to them:-

A majority of the respondents (65) representing $87.84 \%$ are of the view that Kenya Ports Authority have done adequate sensitization to the current and prospective suppliers to the authority on the changes and benefits accrued to them as indicated in figure 4.6 below:

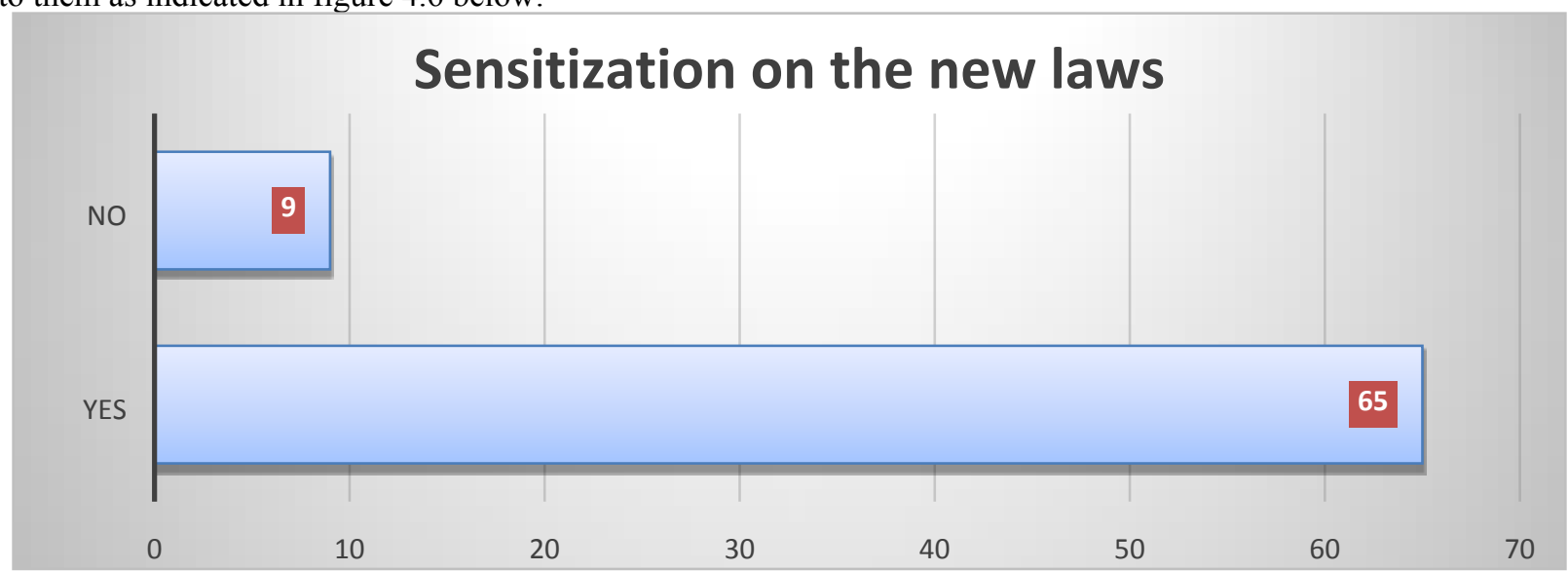

Figure 4.5:- Sensitization on the new laws.

Opinion rating of sensitization by Kenya Ports Authority to Disadvantaged Groups:-

Majority of the respondents' opinions on the scale of sensitization for the Disadvantaged Groups classified as good as shown in the figure below.

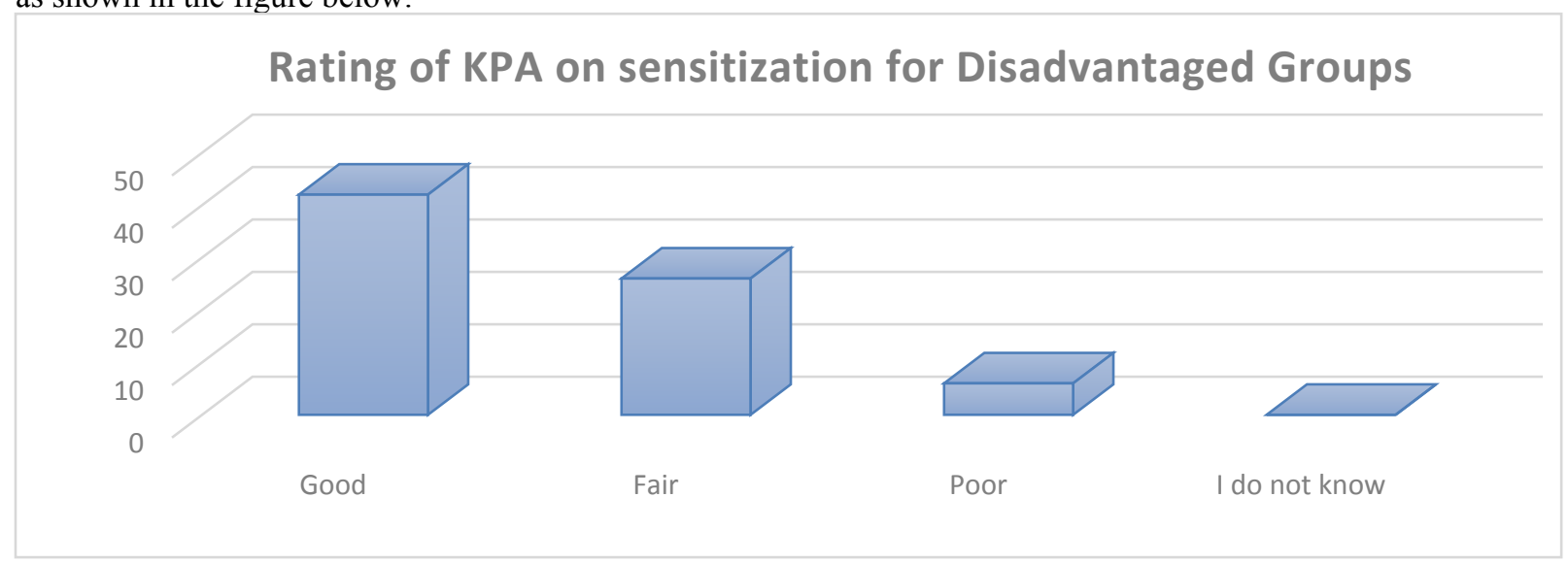

Figure 4.6:- Level of Sensitization for Disadvantaged Groups

\section{Level of education:-}

Majority of the respondents are diploma holders at 39\% meaning they have a reasonable level of education to be able to run business professionally and the least are Masters holders at $6 \%$, degree and certificate holders are taking almost a quarter each 31 and $24 \%$ respectively of the entire sampled population as shown below. 


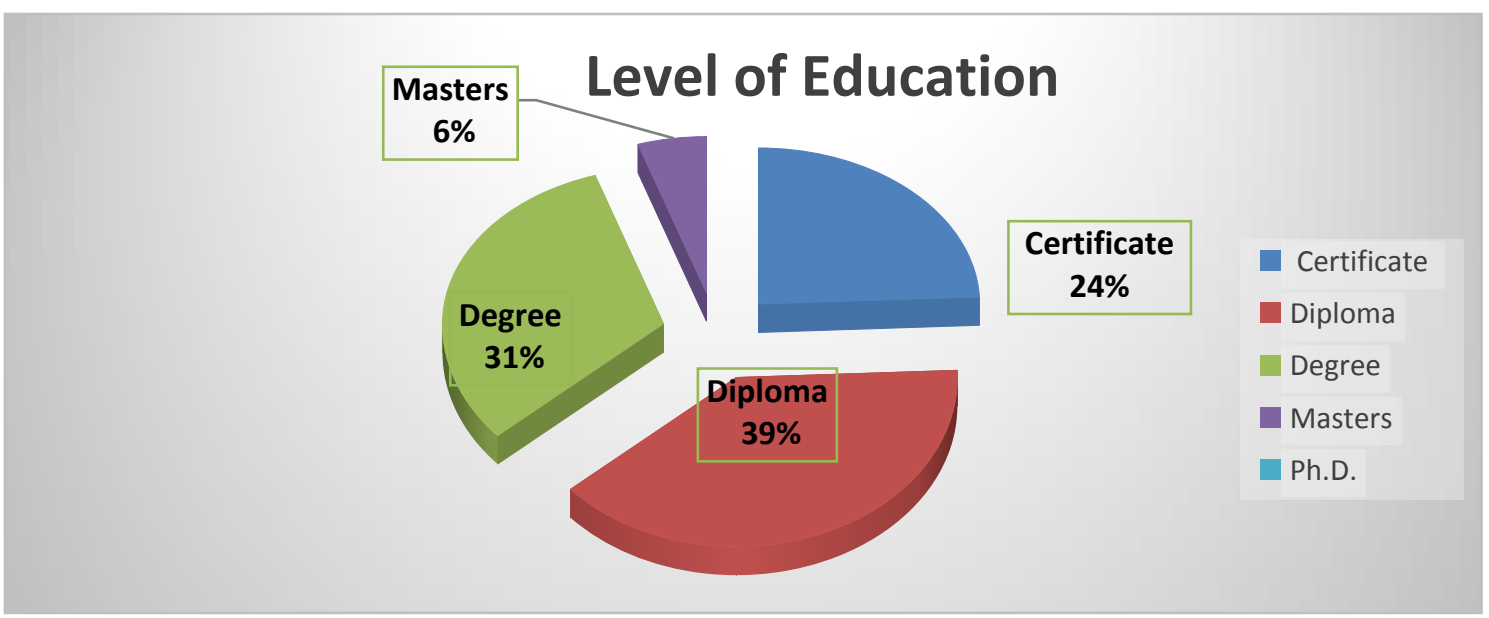

Figure 4.7:- Level of education.

Training on use of online Supplier Relationship Management System:-

As indicated below (64) $86 \%$ of the respondents show that they are trained on the use of online system whereas (10) $14 \%$ have not been trained on the same. The $14 \%$ not yet trained on online system usage could be attributed to new entrance in the business when the training had been done and hence they are yet to get the opportunity to be trained. There was a strong correlation between training and positive responses on the online Supplier Relationship Management System, this supports Kothari (2003) correlation analysis studies between the independent variables and the dependent variable.

\section{Trained on use of Online Supplier Relationship Management System}

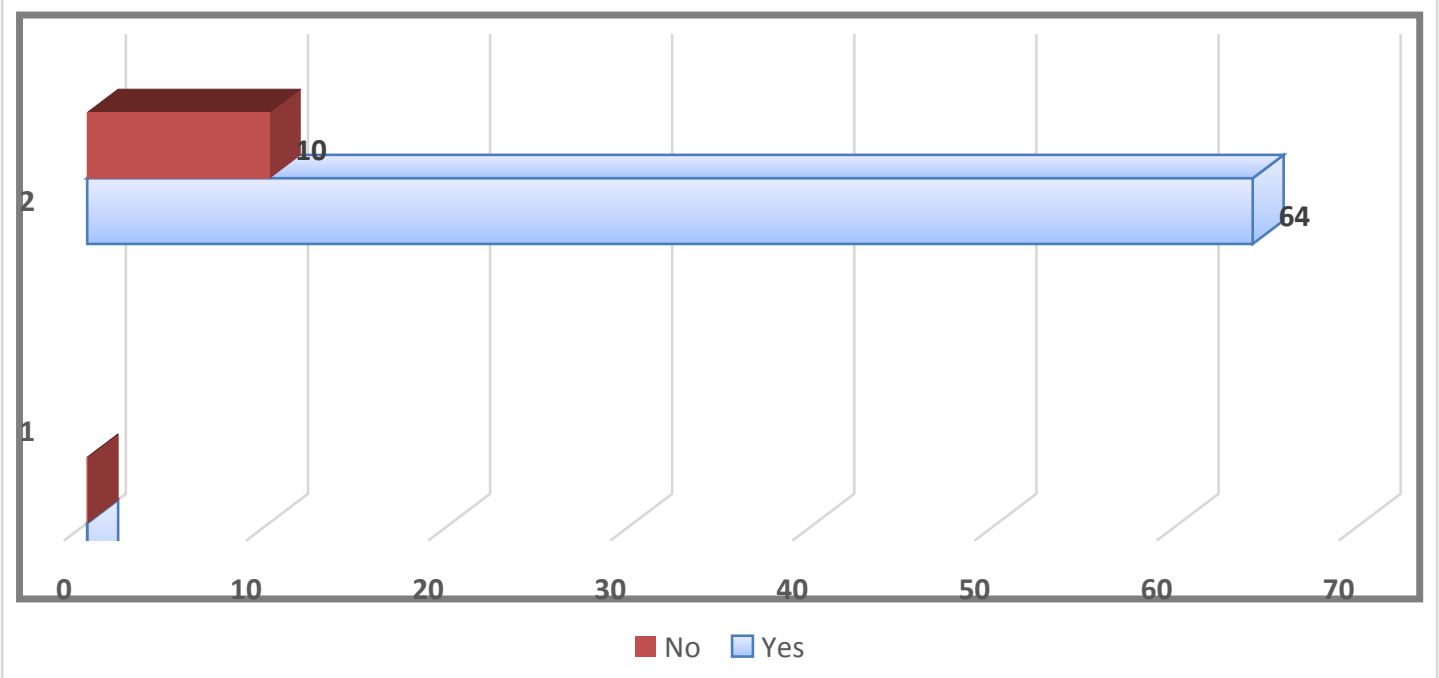

Figure 4.8:- Training on use of Online Supplier Relationship Management System.

Opinion on KPA services offered to preference groups in Procurement processes in regard to disadvantaged groups:-

Majority of the respondents were of the opinion that Kenya Ports Authority offers good services to disadvantaged groups. When asked if equal opportunities was offered to all disadvantaged groups in accessing Supplier Relationship Management System, 78\% say yes and only 22\% was of contrary opinion. Similar percentages were also repeated in opinion on Kenya Ports Authority responds to Supplier Relationship Management System challenges as shown in the table below. 
Table No. 4.1:- Evaluation on Kenya Ports Authority services to special Groups

\begin{tabular}{|c|c|c|c|c|}
\hline Opinion areas by respondents & YES & $\%$ & NO & $\%$ \\
\hline $\begin{array}{l}\text { Kenya Ports Authority offers equal opportunities to all disadvantaged groups in } \\
\text { accessing Supplier Relationship Management System }\end{array}$ & 58 & 78 & 16 & 22 \\
\hline $\begin{array}{l}\text { Kenya Ports Authority offer sufficient training on the use of Supplier Relationship } \\
\text { Management System }\end{array}$ & 50 & 68 & 24 & 32 \\
\hline $\begin{array}{l}\text { Kenya Ports Authority offer immediately solution on areas with challenges on } \\
\text { Supplier Relationship Management System to its Clients }\end{array}$ & 58 & 78 & 16 & 22 \\
\hline $\begin{array}{l}\text { Kenya Ports Authority's Supplier Relationship Management System offer the best } \\
\text { service in process functions }\end{array}$ & 55 & 74 & 19 & 26 \\
\hline
\end{tabular}

Similarly on the training on use of Supplier Relationship Management System, majority(68\%) were in agreement whereas $32 \%$ were of negative opinion. On the offer of immediate solution to challenges expereince during the use of Supplier Relationship Management System, majority(78\%) agrees that Kenya Ports Authority offers immediate solution but still there was a minorty of $22 \%$ which seems not to get immediate solution when they are in need of the same. There was a positive view on the level of service provided by Kenya Ports Authority as shown by $74 \%$ of the respondent whereas a a small group of $26 \%$ were of a different opinion. The response shows a direct co-relation between Accessing Supplier Relationship Management System and offer of immediate solutions to any onlines on Supplier Relationship Management System This leads to satisfaction and level of quality of services offered to disadvantged groups by Kenya Ports Authority. This provides a level of acceptance to the results of this research to represenat an acceptable representation of the data on the subject.

\section{Disadvantaged group Financial Capacity:-}

The financial liquidity of the disadvantaged groups determines the volumes of business they can do. As shown in the table (4.2) below, when asked of accessibility of funds from banks using Kenya Ports Authority purchase orders, most of the respondents 95\% indicate that banks recognize Purchase Orders originating from Kenya Ports Authority while 5\% are of the contrary opinion. Furthermore when asked if Kenya Ports Authority provides Assurance letters on request for LPO financing, 96\% concur that Kenya Ports Authority supports such endeavors. A greater majority $(92 \%)$ do agree that they fear bidding along with others due to inability to access funds.

Table No. 4.2:- Access to Sources of Funding for Disadvantaged groups in KPA.

\begin{tabular}{|c|c|c|c|c|}
\hline Parameters and Responses & YES & $\%$ & NO & $\%$ \\
\hline $\begin{array}{l}\text { All Banks recognize Kenya Ports Authority Purchase Orders to support financing } \\
\text { for Disadvantaged Groups }\end{array}$ & 70 & 95 & 4 & 5 \\
\hline $\begin{array}{l}\text { Kenya Ports Authority supports All Disadvantaged Groups with Assurance letters } \\
\text { for LPO Financing on request }\end{array}$ & 71 & 96 & 3 & 4 \\
\hline $\begin{array}{l}\text { Disadvantaged Groups fear to bid along with others on Kenya Ports Authority } \\
\text { tenders due to inability to access funds }\end{array}$ & 68 & 92 & 6 & 8 \\
\hline
\end{tabular}

The response above data shows co-relation between recognition of Kenya Ports Authority Local Purchase Order and direct LPO financing, this is demonstrated by the banks willing to support financially majority of any disadvantaged persons who have been awarded contracts by Kenya Ports Authority.

\section{Equity Ratio:-}

Majority of the respondents were of the opinion that major shares of disadvantaged groups are being owned by the respective category individuals and that most of them are run under sole proprietorship arrangement.

Table No 4.3:- Equity or Shareholding for Disadvantaged groups.

\begin{tabular}{|c|c|c|c|c|}
\hline $\begin{array}{l}\text { Evaluate the equity of the Disadvantaged Groups in Procurement Processing as } \\
\text { per the Acts } 2015\end{array}$ & YES & $\%$ & NO & $\%$ \\
\hline All Disadvantaged Groups are major shareholders in their respective category & 65 & 87.8 & 9 & 12.2 \\
\hline Disadvantaged Groups are run mostly under sole proprietorship ownership & 63 & 85.1 & 11 & 14.9 \\
\hline Disadvantaged Groups operates as Partnership of several individuals. & 64 & 86.5 & 10 & 13.5 \\
\hline
\end{tabular}


Although there is a majority shareholding in their own category, there is a direct co-relation between those operating as Sole proprietorship and those operating as Partners of several individuals.

\section{Challenges encountered:-}

A greater number of the respondents (63) $85 \%$ were of the opinion that more sensitization needs to be done for disadvantaged groups in Kenya. Equally the same percentage of respondents were of the opinion that there is need to improve the level of customer care to the disadvantaged groups, whereas (70) $95 \%$ concur that frequent training to disadvantaged groups by concerned bodies such as Kenya Institute Supplies Management and Public Procurement Oversight Authority should be enhanced

Table No. 4.4:- Challenges encountered by disadvantaged groups.

\begin{tabular}{|c|c|c|c|c|}
\hline Alleviating the challenges encountered by the Disadvantaged Groups & YES & $\%$ & $\mathrm{NO}$ & $\%$ \\
\hline There is need for more sensitization to Disadvantaged Groups in Kenya & 63 & 85 & 11 & 15 \\
\hline There is need to improve customer care services to Disadvantaged Groups & 63 & 85 & 11 & 15 \\
\hline $\begin{array}{l}\text { There is a need for frequent training to Disadvantaged Groups by concerned } \\
\text { bodies }\end{array}$ & 70 & 95 & 4 & 5 \\
\hline
\end{tabular}

On the Challenges faced by disadvantaged groups operating in Kenya Ports Authority, the results of this research indicates that there is negative co-relation between sensitization on the provision on the new Act to the groups and the frequent training to the disadvantaged groups, this could be attributed to new entrance on the category under this study in Kenya Ports Authority.

\section{Summary, Conclusions \& Recommendations:-}

A population of eighty (80) respondents from a cross three groups was drawn out of 406 targeted group. For purposes of collecting primary data, the researcher developed and administered a questionnaire and the results obtained were analyzed using Microsoft Excel and Statistical Package for Social Sciences (SPSS. Ver 16.020).

\section{Summary:-}

In summary of the whole research, the influence of sensitization on Government Procurement Opportunities to this groups has adequately done by the Authority on behalf of the Government, on education level, the finding indicate that there is reasonable level of education amongst the group with at least Diploma level. On financial capacity, the results shown that All Banks are ready to facilitate financial assistance in terms of loan or any other help towards fulfilling their financial needs to deliver goods, works and Services as per contracts awarded by Kenya Ports Authority. The study outcome shows that majority of the disadvantaged groups are shareholders in their respective category and equally true that most operates as Sole Proprietorship or operates as partnerships.

\section{Conclusions:-}

Kenya Port Authority is among the few government agencies which have successfully adhered to the government requirement on reservation for special groups, they have gone further a step to train the stakeholders and provide online service for all Kenyans to access the same services. Among positive feedback are: A lot have been done on sensitization to Disadvantaged Groups in Kenya, There are good provision for customer care services to Disadvantaged Groups, There are frequent training to Disadvantaged Groups by concerned bodies All Disadvantaged Groups have been covered in consideration to their respective category, There are both sole proprietorship ownership as well as Partnership among Disadvantaged Groups operating in the Port of Mombasa, All Banks recognize Kenya Ports Authority Purchase Order to support financing for Disadvantaged Groups, Kenya Ports Authority supports all Disadvantaged Groups with Assurance letters for Local Purchase Order Financing on request, Kenya Ports Authority offers equal opportunities to all disadvantaged groups in accessing Supplier Relationship Management System, Kenya Ports Authority offer sufficient training on the use of Supplier Relationship Management System and Kenya Ports Authority's Supplier Relationship Management System offer the best service in process functions. The organization just like any other large business group have several challenge which affect their day to day operations, among them are: Disadvantaged Groups fear to bid along with others on Kenya Ports Authority tenders due to inability to access funds, Kenya Ports Authority delays in offering solution on areas with challenges on Supplier Relationship Management System to its Clients and The "Disadvantaged Groups" are facing many shortcomings when it comes to raising capital as they cannot play in the same league with established firms with wide experiences. As derived from the above challenges, the effects of institutional challenge on implementation were found to be strong and are likely to significantly generate some negative impact on the 
intended impact on the society and the overall Government of Kenya long term plan to help the disadvantaged Group, the same is seen from this research which also affect other government agencies in Kenya.

\section{Recommendations:-}

The study recommends that the following institutional challenges should be addressed. Training challenges should be addressed through introduction of several workshops to staff to educate them on the legislation. There is a need to lessen on Political interference and other negative effects through introduction of institutional culture change aimed at creating positive attitudes among the special preference groups and the public at large. It is recommended that all state agencies should utilized Information Communication and Technology to enhance the implementation of special preference regulations. Consideration for the special need towards the groups should be institutionalized to enhance the success on implementation of special preference programs. The study recommends that the regulations should not be only in paper but a step has to be taken to ensure the actual implementation and close monitoring among state corporations. Government should put in place systems to help in sorting out complaints by the Disadvantaged groups. It is also recommended that there is need for more communication especially on all the awards given to special groups among them the Youth, Women and Persons with Disabilities

\section{Areas of Further Research:-}

This study was not exhaustive by any means and therefore it is recommended that in future another study be conducted in Kenya Ports Authority or any other state corporation and concentration be done at level of success on projects or programs given to the disadvantaged groups within the organization. Others areas recommended for further research is Value for Money on contracts awarded to disadvantaged groups.

\section{References:-}

1. Camino, L. (2005). Pitfalls and promising practices of youth-adult partnerships: An evaluator's reflections. Journal of Community Psychology, 33(1), 75-85.

2. Doug, M. \& Scott, W.R. (2004). Organizations and Movements. In Social Movements and Organization Theory, New York: Cambridge University Press

3. González.A. (2014). Empowering Women through Public Procurement. International Trade Centre (ITC).Geneva:

4. Government of Kenya. (2011). The Public Procurement and Disposal (Preference and Reservations) Regulations. Nairobi: Government Printers.

5. Harpe, S. (2009). Public Procurement Law; A comparative analysis. Doctor of Law Thesis, University of South Africa

6. Julia R., Dilani J., (2006). "The financing of disadvantaged entrepreneurs: Are enterprise programmes overcoming the finance gap?", International Journal of Entrepreneurial Behavior \& Research 12(6), 388-400

7. Kothari, C.R., Gaurav G (2014). Research Methodology, Third Edition, New. Age International Publishers, New Delhi

8. Kumar V. (2012). Factors for Successful e-Government Adoption: a Conceptual Framework, Carleton University, Canada

9. Mugenda, O. M. \& Mugenda, A. G. (2009). Research methods: quantitative and qualitative approaches. Nairobi. Acts press

10. Muraguri, J.T. (2013). Implementation of the youth preference and reservations policy in public procurement: The case of state owned enterprises in Nairobi. Unpublished MBA Research Project, University of Nairobi

11. Ngugi, J.K., Mugo H.W. (2012). Internal factors affecting procurement process of supplies in the public sector; a survey of Kenya government ministries. Paper presented at 5th International Public Procurement Conference Seattle, USA.

12. Republic of Kenya. (1978). Kenya Ports Authority Act, (Act No. 2). Nairobi Government Printer.

13. Republic of Kenya. (2015). public procurement and asset disposal act. Nairobi Government Printer.

14. Vincent J. M., Abbie, C. (2011). Sustainable Procurement Policy and strategy. University of Greenwich. University of Greenwich Procurement \& Business Services. Retrieved from:

15. www.gre.ac.uk/offices/procurement 